brazilianpoliticalsciencereview

ART I CLE

\title{
Individual Conditioning Factors of Political Protest in Latin America: Effects of Values, Grievance and Resources
}

\author{
Lucas Toshiaki Archangelo Okado ${ }^{1}$
}

https://orcid.org/0000-0002-9677-7193

\author{
Ednaldo Aparecido Ribeiro ${ }^{2}$ \\ https://orcid.org/0000-0002-4005-5108
}

${ }^{1}$ Universidade Federal de Goiás, Goiânia/GO, Brazil

2Universidade Estadual de Maringá, Maringá/PR, Brazil

Theories about political protest point to three sets of variables responsible for promoting engagement in such actions: resources, grievance and values. There is consensus on the importance of resources, but the influence of grievance and values remain inconclusive. Discontent alone is not enough to motivate protest, but in societies at intermediate levels of development, grievance could be an explanatory variable. By contrast, values would have a limited effect, given that value change in developing countries could only be incipient. In view of the new cycle of protest in the region and wishing to contribute to the debate on the subject, we aim to discover what the relationship is between these three sets of variables as regards Latin Americans' predisposition to protest. Given that these countries find themselves at an intermediate level of economic and social development, it would seem that the primary motivation for protest is discontent, as under such circumstances the relative scarcity of resources presents little obstacle to mobilization. On the other hand, as the societies in question are not advanced industrial societies, the associated low dispersion of emancipatory values would exercise limited effect. To test these hypotheses, we looked at data from the sixth wave of the World Values Survey with reference to Argentina, Brazil, Chile, Colombia, Mexico, Peru and Uruguay. The results suggested that grievance was irrelevant as an explanatory factor. Participation in protests in the region is determined by the mobilization of resources and values.

Keywords: Latin America; political protest; political behavior; emancipatory values; discontent.

http://doi.org/10.1590/1981-3821202000030002

For data replication, see https://doi.org/10.7910/DVN/41MFVV

Correspondence: Lucas Toshiaki Archangelo Okado. E-mail: lucas.okado@gmail.com

This publication is registered under a CC-BY Licence. 
$\mathrm{T}$ he relationship of Latin Americans with protest is complex, since many of their governments have only recently re-democratized. The region lived for many decades with authoritarian regimes that systematically repressed any opposition. The end of this period was preceded by intense protests. Despite appearing in the background in some analyses, strikes and street mobilizations were instrumental in applying pressure during the transition processes, elevating the level of such protests (O'DONNELL and SCHMITTER, 1986) as the 'Marcha de los Suyos' in Peru (VICH, 2004) or the 'Diretas Já' movement in Brazil (BERTONCELO, 2004).

The authoritarian period was marked by the emergence of new social movements (SADER, 1988), whose characteristic was the construction of a democratic identity (SCHRER-WARREN and KRISCHKE, 1987). They arose from the breakdown of traditional agents of mobilization and gave rise to new forms of collective organization (GARRETÓN, 2002). The democratic opening-up period saw newly-inaugurated post-dictatorship regimes enjoying a honeymoon period (INGLEHART and CATTERBERG, 2002) in which there were low rates of participation in protest. As the Peruvian case illustrates, ardor for protest cools once the desired objectives have been partially reached (LEVINE and ROMERO, 2004).

People then returned to the streets as a result of economic reforms during the 1990s. According to Arce and Mangonnet (2013) "These protests were effective in rolling back unpopular economic policies, such as privatizations of natural resources, government utilities, pension systems, and social services" (ARCE and MANGONNET, (2013, p. 896). Environmental, ethnic and agrarian conflicts, as well as those surrounding the redistributive role of the State were at the center of many protest actions in this period in Latin America.

New forms of political activism appeared in the region and were centered on demands for expanded democratization and rights recognition (GARRETÓN, 2002). This was the case with feminist movements that had gained strength during the authoritarian period (BALDEZ, 2003) but have only recently taken to the streets with specific demands. The 'Ni Una a Menos' protests in Uruguay and Argentina in favor of the legalization of abortion, with echoes throughout Latin America, are examples of this phenomenon. The region is going through a new cycle of protests 
that began in Brazil in 2013 and by 2019 had reached Chile, Ecuador and Bolivia. Some of these were framed by such economic issues as increases in the prices of fuel and public transportation, but they also involved pressure on governments for institutional improvements.

The literature points to three sets of variables that affect decisions to participate in protests: resources, grievances and values. Despite appearing as a key variable in classical studies on social movements (GURR, 1970; McADAM, 1999), according to Dalton, Van Sickle and Weldon (2010), there is little empirical evidence to support the effect of discontent on individual engagement. In relation to values, Inglehart (1979) predicted that protests would be incorporated into citizens' daily lives. Changes in the scale of priority given to certain values underlie a reorientation of political participation. Several empirical studies have corroborated these predictions in varied contexts (DALTON, VAN SICKLE and WELDON, 2010; INGLEHART, 1990; INGLEHART and CATTERBERG, 2002), demonstrating that cultural change is related to new patterns of citizenship and engagement.

Resources constitute the third set of conditions for protest: education, free time, money and access to inter-relationship networks are described as important predictors of participation. Political action has costs that need to be borne for it to happen (RIBEIRO and BORBA, 2010), thus more resources imply more participation. Studies on political behavior have converged on a consensus in this respect (ALMOND and VERBA, 1963; VERBA, SCHLOZMAN, and BRADY, 1995).

In order to contribute to the debate on the phenomenon of political protest in Latin America, we seek to understand whether the interaction between the set of variables could explain participation in the local context. The research question that guides this study is: to what extent can protest in Latin America be explained by the interactions between resources, grievance and emancipatory values.

The study of protest in this region may offer a better understanding of this phenomenon. As they are countries at an intermediate level of development, distributive conflicts still persist, but the lack of resources does not inhibit participation. In this context, grievance can motivate protest (DALTON; VAN SICKLE; WELDON, 2010). But at the same time, this characteristic makes the dispersion of emancipatory values incipient, thus reducing their influence on 
protests. The emergence of new social movements in Latin America, with demands related to the expansion of minority rights or the improvement of democratic institutions, are closely related to changes in values and feelings of discontent. An understanding of the relationship between resources, discontent and values and its effect on participation may shed light on recent protests cycles in the region.

This article is organized into five sections. This introduction is followed by a review of the literature on political protest. The next section presents our methodology, and this is followed in turn by our results and discussions thereof. The article closes with a conclusion in which we summarize our findings.

\section{Individual conditioning factors of political protest}

Pioneering studies on political behavior have disregarded the role of protest and restricted the concept of participation to the interaction between citizens and the institutional sphere, mostly through elections (VERBA and NIE, 1972). The collection published by Barnes and Kaase (1979) represents a paradigm shift. Under the auspices of the protests at the end of the 1960s, protest began to be seen as a means of participation, albeit one with an exceptional character, hence 'unconventional participation'. Protest actions have recently become recurrent and have come to represent a wider range of interests and instruments of institutional policy (MEYER and TARROW, 1996), thus rendering the 'unconventional' moniker obsolete (NORRIS, 2003b).

Tilly, Tarrow and McAdam (2009) define protest as a confrontation that "[...] begins when people make collective claims of others whose interests would be affected if those claims were granted" (TILLY, TARROW and McADAM, 2009, p. 11). According to this definition, protest is a distributive or redistributive confrontation involving collective actors and social interactions in which one side makes claims in relation to one or more parties - with the State being one of them. For Inglehart (1990), protests are actions that confront elites. Inglehart (1990) holds on to the idea of conflict involving ordinary citizens and ruling elites (i.e. the government) but his analysis shifts from collective to individual action. His goal is to understand the characteristics that lead citizens to protest. 
Both definitions agree that protests involve conflicts between forces located at opposite poles of the social structure. But from the moment that protest becomes daily in contemporary societies (NORRIS, 2003a), its targets expand. Boycotts that target companies not compliant with ethical social standards, diets adopted in defense of animal rights and women's marches that aim to change social values are examples of a new activism that is not directed at the State or leading elites (DELLA PORTA and DIANI, 2006; NORRIS, 2007).

Quaranta (2015) defines political protest as a direct act of participation without the intermediation of institutionalized channels, carried out voluntarily by ordinary citizens acting collectively or individually with a view to changing some aspect of reality, be it governmental or private. This definition excludes the aspect of conflict and does not establish a precise conceptual framework. It would categorize missionary work as a form of protest. Although missionary work and some feminist movements aim to change social values, the differences between them and protest are clear, especially when the notion of conflict is taken into account.

We have adopted an intermediate position and define protest as voluntary collective or individual act outside of institutionalized settings that aims to confront a given position. This definition is broad but allows room to accommodate changes in the nature of protest, as seen in recent years. Now we turn to the question of how to measure protest empirically.

Political behavior studies divide protest into four types: 01. departure from unconventional acts; 02 . partially legal acts; 03. illegal but not violent acts; and 04. acts involving violence and direct confrontation (DALTON, VAN SICKLE and WELDON, 2010). These lie on a continuum (BORBA, 2012), which ranges from the simplest acts (signing a petition) to the most complex (participating in unofficial strikes).

The sixth wave of the World Values Survey asked about participation in four types of protest: 01. petitions; 02. boycotts; 03. marches; and 04. unofficial strikes. There was also a fifth question about participation in 'other' non-specified acts. The five categories above overlap with three of the four types of protest, excluding involving violence and direct confrontation. Such acts have become less frequent as 
protest is engaged in by more citizens. These same measures are employed in several works on protest ${ }^{1}$.

The literature points to three individual characteristics that can explain participation in protests: resources, grievance and values (DALTON, VAN SICKLE, and WELDON, 2010; QUARANTA, 2015). Resources means the possession of characteristics that make bearable the costs of participation. Grievance comes from the idea of relative deprivation (GURR, 1970) and is a provides a motive for protest. Post-materialist or emancipatory values tend to encourage participation in general, but have a greater effect on protest (INGLEHART, 1979; WELZEL, 2013).

Verba et al. (VERBA and NIE, 1972; VERBA, NIE and KIM, 1971, 1978; VERBA, SCHLOZMAN, and BRADY, 1995) have demonstrated that there is a relationship between resource ownership and activism. Participation requires time, access to information, a network of contacts, and material conditions. Welzel (2013) divides resources into three types: cognitive, material and connective.

'Cognitive resources' may be defined as an individual's level of formal education. For each year of education, there is an increase in the capacity to search for and process political information. This expands the individual's understanding of reality and the means used to direct demands to the political system (DALTON, VAN SICKLE, and WELDON, 2010). This variable has contradictory effects on participation in protests in the countries analyzed. After analyzing participation in Argentina, Alvarez, Levin and Núñez (2017) found that high educational levels were typical of the activists and agitators most likely to lead protest movements. Ribeiro and Borba (2010) found that the same was true of Brazil, Chile and Peru. Valenzuela, Arriagada and Scherman (2012) did not find the same relationship between education and protest among young Chileans living in large urban centers. Frassinetti (2009) expected to find higher levels of participation among Mexican university students but identified levels very close to those of the general population.

Due to the costs of participation, resources tend to enhance engagement. Greater availability of resources is accompanied by more free time and greater

\footnotetext{
${ }^{1}$ See Barnes and Kaase (1979); Dalton, van Sickle, and Weldon (2010); Quaranta (2015); and Ribeiro
} and Borba (2015).

(2020) $14(3) \quad$ - $\quad$ e0002-6/31


probability of success through political action, primarily through contact with powerful people (DELLA PORTA, 2010). In unequal countries, access to education is linked to individuals' incomes. These two variables - income and education partially limit participation to those who have a central position in society, which calls into question the relevance of grievance.

Income and protests participation seem to contradict the centrality model (VERBA, SCHLOZMAN, and BRADY, 1995) in the cases analyzed. Alvarez, Levin and Núñez (2017), found no significant effect on protest participation in Argentina. Ribeiro and Borba (2010) found positive effects for this variable in Peru only. However, Ortiz-Inostroza and López (2017) demonstrate the existence of a curvilinear relationship between income and protest in Chile, as many Chileans fall into intermediate income brackets, which correlates positively with protest participation.

With the popularization of Tocquevillian approaches, several studies have tested the effects of civic engagement on politics (QUARANTA, 2015). For Fiorina (2002) such activities include voluntary actions conducted in communities, workplaces or any other context, which may or may not be political, or may be somewhere in-between. Participation in them provides training in useful skills for the performance of political roles (VERBA, SCHLOZMAN, and BRADY, 1995). It also promotes cognitive shortcuts and calls on participants to take part in political actions (DELLA PORTA and DIANI, 2006; NORRIS, 2003b). The associative fabric and/or the presence of strong leaders mitigate dependence on participation in relation to other types of resources, since they enhance the engagement inhibited of people otherwise hampered by their socio-economic status (UHLANER, 2001).

As parties and unions were dissolved during dictatorships, community associations became spaces where social movements could take root (GARRETÓN, 2002; SADER, 1988). The positive correlation between civic engagement and political participation is well documented. Klesner (2007) finds robust evidence of this correlation for Argentina, Chile, Mexico and Peru. Valenzuela, Arriagada and Scherman (2012) and Ortiz-Inostroza and López (2017) demonstrate a strong relationship between community participation and protest in the Chilean context.

The second protest predictor is grievance. This refers to the notion of relative deprivation, whereby one group of individuals finds itself in a condition 
of scarcity or deprivation of some good or right that is owned by another group (GURR, 1970), a spur to political action. Norris, Walgrave and Aelst (2005) introduce the concept of 'radical disaffection' according to which individuals dissatisfied with the way institutions function are more likely to rise up against them and express themselves through protests, since their lack of trust leads them to seek other ways to express themselves politically. However, their empirical findings do not demonstrate the relationship between radical disaffection and greater participation.

Recent studies use the variable 'satisfaction with democracy' to measure political discontent (QUARANTA, 2015). The responses of European governments to the 2008 economic crisis have led to discontent with democracy, especially among the young (LIMA and ARTILES, 2013). It seems more appropriate to measure grievance, given that this measure captures people's evaluation of the outcomes of democratic government. Trust in institutions can be influenced by positive evaluations of representatives. However, the data used do not contain this variable. We overcame this situation by reference to a trust in institutions index composed of measures related to the legislature, the government, the judiciary and political parties.

For Quaranta (2015), the relationship between discontent and protest depicted in the literature is controversial. His study of protest in Western Europe found no evidence that this variable could explain political protest. But political dissatisfaction was significant in nine of the 19 cases analyzed. For McCarthy and Zald (1977), every society has enough dissatisfied people to trigger collective protests. Dalton, Van Sickle and Weldon (2010) did not find any effect of discontent on protest but stressed that discontent in developing societies was worthy of deeper investigation.

The relationship between these variables in Latin America is also uncertain. In Argentina, Alvarez, Levin and Núñez (2017) found a relationship between perception of national economic performance and the likelihood of political activism, but no effect for personal economic assessment. In Brazil, Mendonça and Fuks (2015) found non-linear effects between life satisfaction and protest. In the case of Chile, Ortiz-Inostroza and López (2017) found negligible 
effects of relative deprivation. Valenzuela, Arriagada and Scherman (2012) found a strong negative relationship between institutional trust and participation in protest among young Chileans. After analyzing the period from 1964 to 2000 in Colombia, Jaramillo (2006) identified an increase in protests due to deterioration on the part of the State to protect well-being.

The last group of variables found in the literature are 'values', defined as a set of beliefs internalized during the socialization process that are manifested latently throughout life (SEARS, 1975) and mediate the interactions of individuals with politics by assigning meanings through a framework of beliefs and attitudes (TESSLER, KONOLD, and REIF, 2004). Inglehart (1979) predicted that value change and the effects of post-materialist values would lead to an increase in protest. To improve this measure, Welzel (2013) proposed an emancipatory value index that would facilitate study of the behavioral effects of cultural change, and quantify the attribution of utility, or subjective value, to freedom.

Values act as a motivation or framework for participation and promote the use of the resources necessary for that participation to take place. By attributing a subjective value to freedom, individuals seek ways to institutionalize it, claiming an extension of rights and demanding more responsiveness from governments, mainly through protests (WELZEL, 2013). People with emancipatory values, who constantly see their goals stymied at the expense of maintaining the status quo, are more likely to participate in protests since they seek the emancipation of minorities, the concession of rights and/or integrity on the part of their leaders.

It is worth noting that the distribution of these values depends on the availability of resources that provide existential empowerment (WELZEL, 2013). In societies where such resources are relatively scarce, as is the case in Latin America, the weight of such values in explaining protests is less than in advanced industrial societies. Many people who share certain beliefs are not in a position to encourage others to join them in protests as the relatively small number of others in similar circumstances limits their ability to come together and organize (DALTON, VAN SICKLE, and WELDON, 2010). Therefore, in the context of Latin America the effects of emancipatory values are reduced, given that objective conditions are hostile to their propagation. 
In view of the foregoing, we have formulated two working hypotheses. The first is that the propensity for protest in Latin American countries depends on the interaction between resources and discontent. Resources are a precondition for participation; without them it is highly unlikely. However, they are dispersed throughout society and lack motivation or framing (BENFORD and SNOW, 2000 ) that could channel them into political action. Grievance, whether due to a subjective life situation or a negative assessment of government performance, can provide an impetus to call on the resources needed for protest to occur.

Because Latin America is at an intermediate stage of economic development, the scarcity of resources does not impose obstacles to participation in protest, which falls within the 'realm of the possible' (MENDONÇA and FUKS, 2015): Grievance exists due to the persistence of distributive conflicts and institutional inefficiencies and resources allow for protest by enabling activists to envision the possibility of transformation through actions taken by them.

$\mathbf{H}_{1}$ : The propensity for political protest in Latin America depends on the interaction between resources and discontent.

Our second working hypothesis is that value change, as measured through emancipatory values, is incapable of explaining protest. There is a consolidated literature that considers the relationship between protest and value change (DALTON, VAN SICKLE, and WELDON, 2010; INGLEHART, 1979; WELZEL, 2013), mainly in advanced industrial societies. In Latin American countries, the phenomenon is perforce incipient, since it is a product of the availability of resources generated by economic development. When analyzing the relationship between political participation and post materialism in Argentina, Brazil, Chile and Uruguay, Ribeiro and Borba (2010) find little empirical evidence that such a relationship exists and recommend a critical adoption of any theory of changing values in Latin America.

$\mathbf{H}_{2}$ : Value change has no effect on protests, given the low dispersion of emancipatory values in the region.

\section{Methodology}

To test the effects of the three sets of variables discussed previously, we looked at data from the sixth wave of the World Values Survey (WVS) project for 
Argentina, Brazil, Chile, Colombia, Mexico, Peru and Uruguay. The World Values Survey provides unique data with the full set of variables described above. No other source surveys Latin America about value change. This limits the number of cases analyzed but allows for testing of all the factors described by the theory. The choice of cases seeks to represent the diversity of the region, but no Central American country was surveyed. Table 01 depicts the characteristics of the samples.

Table 01. Case descriptions

\begin{tabular}{lllll} 
Country & $\mathrm{N}$ & $\mathrm{NC}$ & $\mathrm{IC}$ & Field data \\
\hline Argentina & 1030 & $95 \%$ & $3.1 \%$ & 2013 \\
Brazil & 1486 & $95 \%$ & $2.6 \%$ & 2014 \\
Chile & 1000 & $95 \%$ & $3.0 \%$ & 2012 \\
Colombia & 1512 & $95 \%$ & $3.0 \%$ & 2012 \\
Mexico & 2000 & $95 \%$ & $2.2 \%$ & 2012 \\
Peru & 1210 & $95 \%$ & $2.8 \%$ & 2012 \\
Uruguay & 1000 & $95 \%$ & $3.2 \%$ & 2011
\end{tabular}

Source: Inglehart et al. (2014a).

The dependent variable is a potential protest scale that measures individuals' predisposition to protest (BARNES and KAASE, 1979). It was built from five questions about whether the interviewee had participated in 01 . petitions; 02 . boycotts; 03. peaceful marches; 04. strikes; and/or 05) other forms of protest. These variables were coded as $1=$ never participated, $2=$ could participate and $3=$ have already participated and standardized on a scale of amplitude from 0 to 10 . Table 02 presents the validation of this construct through factor analysis, made from a polychoric correlation matrix. The Kaiser criterion was used to define the number of factors and, in all cases, only one factor was extracted. As can be seen, the potential protest scale is invariant between cases and measures the same phenomenon in all countries, which makes it a worthy tool for our purposes.

Education was recoded on a scale of low, medium and high. The WVS divides this variable into nine points, so we grouped values from 01 to 04 (up to complete elementary school) as low; values from 05 to 07 (complete high school) as medium; and the last two points, 08 and 09 (higher education) as high. The reference category is low education, which means that the coefficients of the other categories express differences in relation to this point. 
Table 02. Factorial analysis of potential protest scale by country

\begin{tabular}{llllllll}
\hline Actions & Argentina & Brazil & Chile & Colombia & Mexico & Peru & Uruguay \\
\hline Petition signing & 0.7 & 0.57 & 0.74 & 0.59 & 0.59 & 0.63 & 0.72 \\
Boycotting & 0.71 & 0.65 & 0.7 & 0.88 & 0.62 & 0.66 & 0.87 \\
Peaceful demonstrations & 0.87 & 0.85 & 0.92 & 0.84 & 0.79 & 0.74 & 0.91 \\
Striking & 0.8 & 0.77 & 0.9 & 0.86 & 0.8 & 0.8 & 0.87 \\
Other protest actions & 0.91 & 0.84 & 0.84 & 0.77 & 0.85 & 0.51 & 0.94 \\
KMO & 0.82 & 0.81 & 0.83 & 0.84 & 0.8 & 0.65 & 0.84 \\
\% Var. Explained by 1 & $64 \%$ & $55 \%$ & $68 \%$ & $63 \%$ & $54 \%$ & $46 \%$ & $75 \%$ \\
factor & & & & & & & \\
Cronbach's $\alpha$ & 0.83 & 0.77 & 0.84 & 0.82 & 0.76 & 0.72 & 0.86 \\
\hline
\end{tabular}

Source: Inglehart et al. (2014b).

Membership of associations is measured by nine variables concerning active or inactive participation in such organizations ${ }^{2}$. These measures fall into three categories where 0 = 'not belonging'; 1 = 'inactive membership'; and 2 = 'active membership'. Unlike the potential protest measure, membership of associations did not behave in an invariant way, since in Brazil, Peru and Uruguay more than one factor was extracted. The theory suggests that membership of associations tends to increase engagement, since associations are sources of social capital (PUTNAM, 2001) and civic learning (VERBA, SCHLOZMAN, and BRADY, 1995). This measure was recoded into a binary variable, where $0=$ does not participate in any association' and 1 = 'participates in one or more associations'.

Grievance, on the other hand, is represented by a 10-point scale that ranks the interviewee's life satisfaction, where 1 = 'very dissatisfied' and 10 = 'very satisfied'. Although satisfaction with democracy is useful to measure political discontent, the WVS database does not contain this variable for the period analyzed. To circumvent this, we referred to an index of trust in institutions constructed from four variables that question the degree of trust in the judiciary, government, political parties and congress. It is a 4point Likert scale, recoded to $1=$ 'no trust', $2=$ 'little trust', $3=$ 'trust' and $4=$ 'complete trust'. It is assumed that the citizens who most unhappy with the functioning of key institutions also feel greater distrust towards them. Like the potential protest scale, this institutional trust measure proved invariant for all cases, as shown in Table 03.

\footnotetext{
${ }^{2}$ Sport or recreation, cultural or educational, unions, political parties, environment, professionals,
} charity, consumers and self-help. 
Table 03. Factorial analysis of trust in institutions scale by country

\begin{tabular}{llllllll}
\hline Actions & Argentina & Brazil & Chile & Colombia & Mexico & Peru & Uruguay \\
\hline Judiciary & 0.65 & 0.62 & 0.73 & 0.76 & 0.72 & 0.77 & 0.61 \\
$\begin{array}{l}\text { Government (executive } \\
\text { branch) }\end{array}$ & 0.76 & 0.81 & 0.75 & 0.82 & 0.79 & 0.82 & 0.82 \\
Political parties & & & & & & & \\
Parliament & 0.8 & 0.81 & 0.83 & 0.77 & 0.8 & 0.86 & 0.82 \\
KMO & 0.93 & 0.84 & 0.91 & 0.85 & 0.85 & 0.88 & 0.93 \\
\% Var. Explained by 1 factor & 0.78 & 0.73 & 0.8 & 0.75 & 0.78 & 0.8 & 0.78 \\
Cronbach's $\alpha$ & $63 \%$ & $60 \%$ & $65 \%$ & $64 \%$ & $62 \%$ & $69 \%$ & $65 \%$ \\
\hline
\end{tabular}

Source: Inglehart et al. (2014b).

Emancipatory values are measured on a scale of 0 to 1 . This measure is formed from four sub-indices that measure autonomy, choice, equality and voice. All of these scales are then regrouped into a single index that measures human empowerment (WELZEL, 2013). The validity of these measures in the context of the countries in this study is shown to be invariant and with a higher degree of reliability than the post-materialism measure, as demonstrated by Okado and Ribeiro (2017).

The linear model presented $N=5,500$, with an exclusion of 3,738 (68\%) cases due to the existence of omitted values. Such absence is justified by the number of independent variables: if a case has an omission in any one of them, it excludes the case from the model. The literature identifies different types of missing cases according to their probability of occurrence (KING et al., 2001). There are no reliability tests to deal with this type of situation and their classification depends entirely on the judgment of each researcher (TANASOIU and COLONESCU, 2008). The questions presented to respondents by the WVS do not deal with sensitive or complex topics so we can assume that most non-answers are random.

In these situations, where the presence of missing cases is random, multivariate imputation by chained equations (MICE) may be employed to attribute the missing values of the variables (BUUREN and GROOTHUIS-OUDSHOORN, 2011). MICE is a series of concatenations of univariate procedures to fill in the missing values in the variables. Through this procedure, the missing data were imputed.

Eight linear regression models were constructed, taking the potential protest scale as a dependent variable. As independent variables, education, income, membership of associations, discontent, institutional trust and emancipatory values 
were included, in addition to sex and age as controls. This last variable has been identified as an important predictor of protests.

Changes in the way young people relate to politics (NORRIS, 2003b) or the dissatisfaction of more recent generations with the functioning of democracies (LIMA and ARTILES, 2013) have led this group to express themselves politically through protest. In the context of the countries analyzed, Ribeiro and Borba (2010) found no evidence that age is a factor that affects protest in Argentina, Chile or Brazil. A similar result was demonstrated by Alvarez, Levin and Núñez (2017) when they analyzed participation profiles in Argentina. Only the Chilean case studied by Ortiz-Inostroza and López (2017) indicates a greater predisposition for young people to participate in protests. The influence of age on engagement may be related to period effects produced by protest cycles, which would explain the inconsistency of the results in these studies.

The dependent variable does not present normal distribution, but recent studies claim that this assumption is not necessary when using linear regressions (WOOLDRIDGE, 2003). Residual analysis was performed, as shown in the methodological appendix. The first model involves all cases and a categorical variable for countries was included, taking Argentina as a reference category. The other seven models describe the determinants of protest in each of the cases analyzed in this study.

\section{Results and discussions}

Table 04 shows the percentages of respondents in each country who responded to having participated in some types of protests. Comparing the fifth (2005 - 2009) and the sixth (2010-2014) wave, a certain amount of stagnation can be seen. Participation in petitions has declined in most countries. Colombia, however, showed positive variation above the research's margin of error. The variation in Chile (3\%) and Mexico (-1\%) fell short of the margin of error, which indicates stability.

This stability is found for participation in boycotts, with less variation than the margin of error. Again, Colombia is an exception, registering a significant increase. The number of people who reported having participated in 
demonstrations remained stable in Argentina and Brazil. In Chile and Colombia there was an increase, slightly exceeding the margin of error. Falls were recorded in Mexico, Uruguay and Peru, being most significant in Peru. In general terms, Peru saw the greatest disengagement in protests, given that $-10 \%$ of the population claimed to have taken to the streets and $-9 \%$ said they had signed a petition. The other two categories, boycotts and 'other forms of protest', showed negative variation, but still within the margin of error.

Table 04. Evolution of protest actions

\begin{tabular}{|c|c|c|c|c|c|c|c|c|c|c|}
\hline & \multicolumn{2}{|l|}{ Petition } & \multicolumn{2}{|l|}{ Boycott } & \multicolumn{2}{|c|}{ Demonstration } & \multicolumn{2}{|c|}{ Strike } & \multicolumn{2}{|c|}{ Others } \\
\hline & W5 & W6 & W5 & W6 & W5 & W6 & W5 & W6 & W5 & W6 \\
\hline Argentina & $28.7 \%$ & $21.1 \%$ & $3.1 \%$ & $3.4 \%$ & $18.7 \%$ & $15.9 \%$ & - & $12.1 \%$ & $0 \%$ & $7.4 \%$ \\
\hline Brazil & $55.3 \%$ & $43.5 \%$ & $7.6 \%$ & $4.3 \%$ & $18.1 \%$ & $15.4 \%$ & - & $12.2 \%$ & $0.8 \%$ & $8.6 \%$ \\
\hline Chile & $18.2 \%$ & $21.4 \%$ & $2.9 \%$ & $04 \%$ & $18 \%$ & $23.1 \%$ & - & $16.4 \%$ & $0.7 \%$ & $15.7 \%$ \\
\hline Colombia & $15.1 \%$ & $23.8 \%$ & $2.4 \%$ & $13.2 \%$ & $13.7 \%$ & $18.3 \%$ & - & $7.3 \%$ & $0.2 \%$ & $5.4 \%$ \\
\hline Mexico & $19.7 \%$ & $18.3 \%$ & $2.7 \%$ & $2.5 \%$ & $15.7 \%$ & $10.2 \%$ & - & $5.5 \%$ & $2.3 \%$ & $4.2 \%$ \\
\hline Peru & $24 \%$ & $13.6 \%$ & $4.7 \%$ & $1.7 \%$ & $23.7 \%$ & $14.2 \%$ & - & $9.5 \%$ & $01 \%$ & $0.1 \%$ \\
\hline Uruguay & $29.6 \%$ & $23.1 \%$ & $1.9 \%$ & $2.4 \%$ & $18 \%$ & $13 \%$ & - & $11.7 \%$ & $0.5 \%$ & $4.1 \%$ \\
\hline $\mathrm{X}^{2}$ & $1295.9 * * *$ & $565.8^{* * *}$ & $314.2^{* * *}$ & $502.3^{* * *}$ & $348.7^{* * *}$ & $502.3^{* * *}$ & - & $279.8^{* * *}$ & - & $398.6^{* * *}$ \\
\hline
\end{tabular}

Source: Inglehart et al. (2014c).

Note: ${ }^{*} \mathrm{p}<0.0{ }^{* *} \mathrm{p}<0.01{ }^{* * *} \mathrm{p}<0.001$. The $\mathrm{X}^{2}$ value was calculated for all categories.

Uruguay also showed a reduction similar to that experienced by Peru, but to a smaller degree. Participation in petitions had a difference of $-6.5 \%$ between the fifth and sixth waves, while participation in marches was $-5 \%$. But, unlike Peru, in the other two categories in which it is possible to make a comparison there was growth, not exceeding the margin of error. In the remaining countries, the variation remained stable. In Chile, there was growth in at least two categories and in Colombia in all cases.

Graph 01 shows average emancipatory values and the potential protest scale. Scores from the assessment of the performance of the democracy ${ }^{3}$, produced by the Varieties of Democracy project, were also included. With only seven cases at the macro level, the derived inferences are fragile. However, we can see that Argentina, Brazil and Colombia have the highest incidence of protest but not the highest average emancipatory values. The same is true of the quality of democracy, a criterion according to which Uruguay and Chile are best evaluated but whose citizens are not the most likely to protest.

\footnotetext{
${ }^{3}$ This measure corresponds to the liberal component of democracy that considers the protection of individual freedoms, freedom of expression and the rule of law. For more information on the measure, see Coppedge et al. (2017a).
} 
Due to the small number of cases, it is not possible to question the findings of Dalton, Van Sickle and Weldon (2010), who claim that democracy favors protests.

Graph 01. Average emancipatory values and the potential protest scale

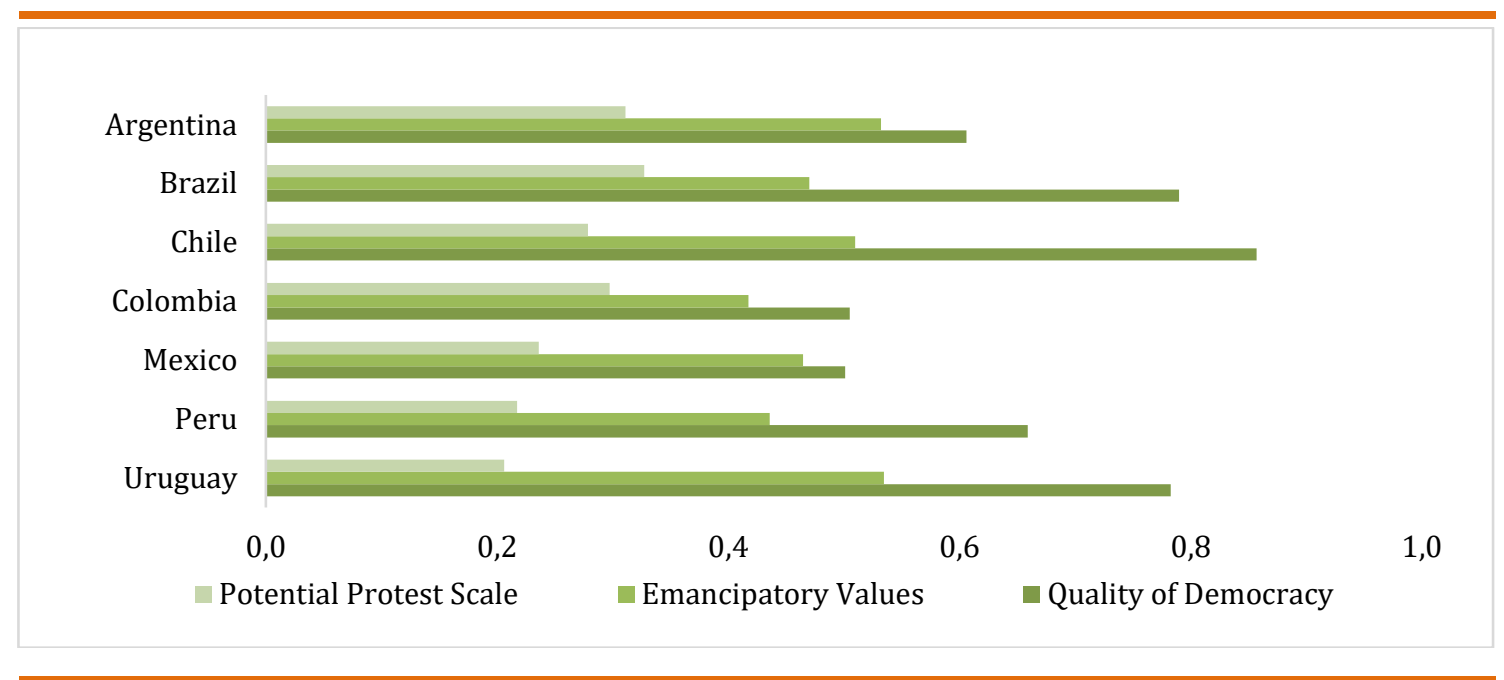

Source: Inglehart et al. (2014b) and Coppedge et al. (2017b).

Moving on to the analysis of multivariate models, Table 05 shows the regression coefficients of the conditions of political protest. The first model involves all cases and also has the variable 'country' as a nominal measure, with Argentina as a reference category, since protests are frequent there and have been incorporated into the daily lives of citizens (ARCE and MANGONNET, 2013). Only Brazilians showed a greater predisposition to protest. Brazil has gone through a cycle of protest in recent years, mainly since the protest wave of June 2013 (TATAGIBA and GALVÃO, 2019) ${ }^{4}$.

In other cases, the levels of participation in this type of protest are lower. The exception is Colombia, where the coefficient was not significant, indicating that Colombians showed a predisposition to protest very close to that of Argentines and only inferior to Brazilians. For Rodríguez (2016), the peace processes initiated in 2012 allowed room for demands that had been systematically blocked from the public agenda by the conflict between paramilitaries, the army and guerrilla groups. This, combined with movements' ability to expand their discourses, call on diverse

${ }^{4}$ Table 05 presents the gross coefficients in the model. Standardized coefficients are described in Table S1, in the methodological appendix.

$$
\text { (2020) } 14(3) \quad \text { e0002-16/31 }
$$


actors and build robust organizational structures were responsible for triggering a cycle of protests from 2010.

Table 05. Potential protest in Latin American countries

\begin{tabular}{|c|c|c|c|c|c|c|c|c|}
\hline & General & Argentina & Brazil & Chile & Colombia & Mexico & Peru & Uruguay \\
\hline & $\begin{array}{c}\text { B } \\
\text { (E. Pad) }\end{array}$ & $\begin{array}{c}\text { B } \\
\text { (E. Pad) }\end{array}$ & $\begin{array}{c}\text { B } \\
\text { (E. Pad) }\end{array}$ & $\begin{array}{c}\text { B } \\
\text { (E. Pad) }\end{array}$ & $\begin{array}{c}\text { B } \\
\text { (E. Pad) }\end{array}$ & $\begin{array}{c}\text { B } \\
\text { (E. Pad) }\end{array}$ & $\begin{array}{c}\text { B } \\
\text { (E. Pad) }\end{array}$ & $\begin{array}{c}\text { B } \\
\text { (E. Pad) }\end{array}$ \\
\hline Intercept & $\begin{array}{l}1.79^{* * *} \\
(0.19)\end{array}$ & $\begin{array}{l}1.97^{* * *} \\
(0.60)\end{array}$ & $\begin{array}{l}2.70^{\text {*** }} \\
(0.42)\end{array}$ & $\begin{array}{l}1.05 \\
(0.66)\end{array}$ & $\begin{array}{l}2.55^{* * *} \\
(0.47)\end{array}$ & $\begin{array}{l}1.83^{* * *} \\
(0.35)\end{array}$ & $\begin{array}{l}0.57 \\
(0.43)\end{array}$ & $\begin{array}{l}-0.47 \\
(0.48)\end{array}$ \\
\hline Sex & $\begin{array}{l}-0.42^{* * *} \\
(0.05)\end{array}$ & $\begin{array}{l}-0.38^{*} \\
(0.15)\end{array}$ & $\begin{array}{l}-0.66^{* * *} \\
(0.12)\end{array}$ & $\begin{array}{l}-0.51^{* *} \\
(0.17)\end{array}$ & $\begin{array}{l}-0.38^{* *} \\
(0.12)\end{array}$ & $\begin{array}{l}-0.45^{\text {*** }} \\
(0.09)\end{array}$ & $\begin{array}{l}-0.30^{*} \\
(0.13)\end{array}$ & $\begin{array}{l}-0.35^{*} \\
(0.14)\end{array}$ \\
\hline Age & $\begin{array}{l}-0.01^{* * *} \\
(0.00)\end{array}$ & $\begin{array}{l}-0.00 \\
(0.00)\end{array}$ & $\begin{array}{l}-0.02^{* * *} \\
(0.00)\end{array}$ & $\begin{array}{l}-0.01 \\
(0.01)\end{array}$ & $\begin{array}{l}-0.01^{* *} \\
(0.00)\end{array}$ & $\begin{array}{l}-0.00 \\
(0.00)\end{array}$ & $\begin{array}{l}-0.00 \\
(0.00)\end{array}$ & $\begin{array}{l}0.00 \\
(0.00)\end{array}$ \\
\hline $\begin{array}{l}\text { Low } \\
\text { education } \\
\text { level }\end{array}$ & - & - & - & - & - & - & - & - \\
\hline $\begin{array}{l}\text { Average } \\
\text { education } \\
\text { level }\end{array}$ & $\begin{array}{l}0.49^{* * *} \\
(0.06)\end{array}$ & $\begin{array}{l}0.48^{* *} \\
(0.18)\end{array}$ & $\begin{array}{l}0.65^{* * *} \\
(0.14)\end{array}$ & $\begin{array}{l}0.23 \\
(0.22)\end{array}$ & $\begin{array}{l}0.73^{* * *} \\
(0.15)\end{array}$ & $\begin{array}{l}0.37^{* *} \\
(0.11)\end{array}$ & $\begin{array}{l}0.22 \\
(0.16)\end{array}$ & $\begin{array}{l}0.59^{* * *} \\
(0.17)\end{array}$ \\
\hline $\begin{array}{l}\text { High } \\
\text { education } \\
\text { level }\end{array}$ & $\begin{array}{l}1.53^{* * *} \\
(0.08)\end{array}$ & $\begin{array}{l}1.71^{* * *} \\
(0.26)\end{array}$ & $\begin{array}{l}1.94^{* * *} \\
(0.18)\end{array}$ & $\begin{array}{l}0.71^{*} \\
(0.30)\end{array}$ & $\begin{array}{l}2.11^{* * *} \\
(0.18)\end{array}$ & $\begin{array}{l}1.19^{* * *} \\
(0.15)\end{array}$ & $\begin{array}{l}1.17^{* * *} \\
(0.19)\end{array}$ & $\begin{array}{l}1.43^{* * *} \\
(0.25)\end{array}$ \\
\hline Income & $\begin{array}{l}-0.02 \\
(0.01)\end{array}$ & $\begin{array}{l}-0.10 \\
(0.05)\end{array}$ & $\begin{array}{l}-0.05 \\
(0.03)\end{array}$ & $\begin{array}{l}0.01 \\
(0.05)\end{array}$ & $\begin{array}{l}-0.04 \\
(0.03)\end{array}$ & $\begin{array}{l}0.01 \\
(0.02)\end{array}$ & $\begin{array}{l}-0.02 \\
(0.04)\end{array}$ & $\begin{array}{l}0.10^{*} \\
(0.04)\end{array}$ \\
\hline $\begin{array}{l}\text { Membership } \\
\text { of } \\
\text { associations }\end{array}$ & $\begin{array}{l}0.64^{* * *} \\
(0.05)\end{array}$ & $\begin{array}{l}0.65^{* * *} \\
(0.16)\end{array}$ & $\begin{array}{l}0.56^{* * *} \\
(0.12)\end{array}$ & $\begin{array}{l}0.98^{* * *} \\
(0.18)\end{array}$ & $\begin{array}{l}0.61^{* * *} \\
(0.13)\end{array}$ & $\begin{array}{l}0.57^{* * *} \\
(0.09)\end{array}$ & $\begin{array}{l}0.43^{* * *} \\
(0.12)\end{array}$ & $\begin{array}{l}0.92^{* * *} \\
(0.16)\end{array}$ \\
\hline Grievance & $\begin{array}{l}-0.04^{* * *} \\
(0.01)\end{array}$ & $\begin{array}{l}-0.05 \\
(0.05)\end{array}$ & $\begin{array}{l}0.01 \\
(0.03)\end{array}$ & $\begin{array}{l}-0.03 \\
(0.05)\end{array}$ & $\begin{array}{l}-0.13^{* * *} \\
(0.03)\end{array}$ & $\begin{array}{l}-0.06^{* *} \\
(0.02)\end{array}$ & $\begin{array}{l}-0.02 \\
(0.03)\end{array}$ & $\begin{array}{l}-0.04 \\
(0.04)\end{array}$ \\
\hline $\begin{array}{l}\text { Trust in } \\
\text { institutions }\end{array}$ & $\begin{array}{l}0.06^{* * *} \\
(0.01)\end{array}$ & $\begin{array}{l}-0.02 \\
(0.03)\end{array}$ & $\begin{array}{l}0.08^{* * *} \\
(0.02)\end{array}$ & $\begin{array}{l}0.02 \\
(0.03)\end{array}$ & $\begin{array}{l}0.11^{\text {*** }} \\
(0.02)\end{array}$ & $\begin{array}{l}0.07^{* * * *} \\
(0.02)\end{array}$ & $\begin{array}{l}0.08^{* * *} \\
(0.02)\end{array}$ & $\begin{array}{l}0.05^{*} \\
(0.02)\end{array}$ \\
\hline $\begin{array}{l}\text { Emancipatory } \\
\text { values }\end{array}$ & $\begin{array}{l}3.23^{* * *} \\
(0.17)\end{array}$ & $\begin{array}{l}3.93^{* * *} \\
(0.49)\end{array}$ & $\begin{array}{l}3.38^{* * *} \\
(0.43)\end{array}$ & $\begin{array}{l}4.76^{* * *} \\
(0.54)\end{array}$ & $\begin{array}{l}2.84^{* * *} \\
(0.45)\end{array}$ & $\begin{array}{l}1.52^{* * *} \\
(0.33)\end{array}$ & $\begin{array}{l}3.76^{* * *} \\
(0.49)\end{array}$ & $\begin{array}{l}3.62^{* * *} \\
(0.49)\end{array}$ \\
\hline Argentina & - & - & - & - & - & - & - & - \\
\hline Brazil & $\begin{array}{l}0.43^{* * *} \\
(0.09)\end{array}$ & - & - & - & - & - & - & - \\
\hline Chile & $\begin{array}{l}-0.39^{* * *} \\
(0.10)\end{array}$ & - & - & - & - & - & - & - \\
\hline Colombia & $\begin{array}{l}0.02 \\
(0.10)\end{array}$ & - & - & - & - & - & - & - \\
\hline Mexico & $\begin{array}{l}-0.74^{* * *} \\
(0.09)\end{array}$ & - & - & - & - & - & - & - \\
\hline Peru & $\begin{array}{l}-0.81^{* * *} \\
(0.10)\end{array}$ & - & - & - & - & - & - & - \\
\hline Uruguay & $\begin{array}{l}-0.96^{* * *} \\
(0.10)\end{array}$ & - & - & - & - & - & - & - \\
\hline $\mathrm{N}$ & 9238 & 1030 & 1486 & 1000 & 1512 & 2000 & 1210 & 1000 \\
\hline $\begin{array}{l}\mathrm{R}^{2} / \text { adjusted } \\
\mathrm{R}^{2}\end{array}$ & $\begin{array}{l}0.190 / 0 . \\
188\end{array}$ & $\begin{array}{l}0.167 / 0.1 \\
60\end{array}$ & $\begin{array}{l}0.226 / 0 . \\
222\end{array}$ & $\begin{array}{l}0.160 / 0.1 \\
52\end{array}$ & $\begin{array}{l}0.226 / 0.2 \\
21\end{array}$ & $\begin{array}{l}0.129 / 0 . \\
126\end{array}$ & $\begin{array}{l}0.143 / 0 . \\
137\end{array}$ & $\begin{array}{l}0.198 / 0.1 \\
91\end{array}$ \\
\hline
\end{tabular}

Source: Inglehart et al. (2014b).

Note: ${ }^{*} \mathrm{p}<0.05 * * \mathrm{p}<0.01{ }^{* * *} \mathrm{p}<0.001$.

Regarding resources, income was not significant, which partially corroborates previous studies (ALVAREZ, LEVIN, and NÚÑEZ, 2017; RIBEIRO and BORBA, 2010) and contradicts the centrality thesis (VERBA, SCHLOZMAN, and 
BRADY, 1995). It is not necessarily people occupying central positions in the social structure that engage in protest. Nonetheless, education coefficients show that this is an important resource. Less educated people tend to participate less when compared to members of other categories. A high education level represents the greatest explanatory factor in relation to propensity to protest. The fact of belonging to an association enhances participation, being the third most robust predictor, behind only education and emancipatory values.

Discontent showed a low coefficient, when compared to the effects of education and association membership. Satisfaction with life reduces the probability of protesting in a statistically significant way, but the effect is very small. The same occurs with trust in institutions, whose positive effect, contrary to the initial expectations of the literature (ARCE and MANGONNET, 2013; NORRIS, WALGRAVE, and AELST, 2005), is almost negligible, confirming the irrelevance of grievance to explain protest.

Emancipatory values are significant in all contexts analyzed. As the theory predicted, this set of beliefs represents an emancipatory impetus, serving as a necessary motivation for citizens to seek changes through protest and overcoming, in motivational terms, their feelings of discontent. Although it is not possible to postulate that the nature of political conflict has changed in Latin America, as described by Inglehart (1990) in advanced industrial societies, change is nonetheless underway, since emancipatory values are very significant in a context where objective living conditions are not as permissive as those of advanced industrial countries.

What the model presented in Table 05 indicates is that the nature of political conflict is also beginning to be guided by values not necessarily related to distribution of wealth. This is evident from the recent social movements such as the Marijuana March, 'Slut Walks', the 'Ni Una a Menos' protests and marches for the legalization of abortion in Uruguay and Argentina. Political conflicts, even in the context of developing countries such as those of Latin America, are also organized around values, such as individual freedom and gender equality.

Analyzing the control variables, gender was significant, although with a modest effect. The gender difference is still noticeable, indicating that women are 
less likely to be involved in protests. The analyzed countries did not address gender differences, since they originate in the socialization process and the roles attributed to women (QUARANTA, 2015). Age was significant, indicating that younger individuals tend to protest more. Since instrumental calculations about whether to engage in protest is greater among adults, who are more integrated into society and lose more in the case of repression, effective participation is greater among younger people (OKADO and RIBEIRO, 2015).

Comparing the general model with the others, we can observe that the results are replicated in all countries. Income showed modest results only for Uruguay. An intermediate education level did not influence protest in Chile. A high education level was significant in all countries, proving that its effect on politics, described since Almond and Verba (1963) applies to Latin America. Membership of associations had relevant effects everywhere but Argentina. It can be concluded that education and belonging to organizations, that is, cognitive and connective resources, are the main resources responsible for the propensity of individuals to protest in the countries we analyzed.

Life satisfaction did not negatively affect Brazil, Chile or Uruguay. In all other cases in which this measure had a satisfactory level of significance, the coefficients are reduced, indicating that its effects are limited to the point that it cannot be concluded that it is relevant to explain predisposition to protest. Our first working hypothesis (H1), which stated that in societies with an intermediate degree of development, resources and grievance would be the main determinant of protests, was not confirmed.

Nor is it possible to conclude that dissatisfaction with the functioning of democratic institutions influences protest. It was expected that there would be a negative relationship between the predisposition to protest and trust in institutions, but the results point in precisely the opposite direction. It is the people who most trust institutions that are most likely to protest. But the coefficients found are limited and do not affect all cases uniformly. In Argentina, Chile and Peru they did not produce significant effects. For the other cases, trust in institutions increases predisposition to protest.

This result is even more relevant in Colombia and Mexico, where trust in institutions generates an effect in the same order as emancipatory values, 
the second highest coefficient in the general model. In these two cases there were changes in institutional aspects, opening up structures of opportunity for mobilization. The election of Mexican President Vicente Fox in 2000 marked the end of the Institutional Revolutionary Party's 70-year hegemony (HISKEY and BOWLER, 2005). Colombia began peace processes and the absorption of insurgent groups into its party system (RODRÍGUEZ, 2016). The incorporation of new actors into the institutional political system increased access to channels for expressing demands, previously blocked by the hegemony of a single party or armed conflict. Demands from actors that previously had no voice in the representative system started to be heard.

Emancipatory values proved to be significant and have a high coefficient in all cases. People who share such values are more likely to protest, contrary to our initial working hypothesis. It was expected that the effects produced by this variable would be limited, given that the dispersion of these values in developing societies would be incipient $\left(\mathrm{H}_{2}\right)$. Although there are people who identify with these beliefs, their small number and sparse dispersion would inhibit the organizing of collective actions (DALTON, VAN SICKLE, and WELDON, 2010). Ribeiro and Borba (2010) have emphasized the need for critical use of the theory of cultural change in the context of Latin America as an explanatory factor for political participation.

The period of economic growth motivated by the rise in commodity prices increased per capita income in the region. At the same time, inequalities have been reduced since the 2000s (LUSTIG et al., 2016). The availability of resources increases the dispersion of emancipatory values. On the other hand, despite proposing the measurement of very similar phenomena, Welzel's emancipatory value index (2013) is much more robust when compared to the postmaterialism measure developed by Inglehart (1990), when applied in the Latin American context (OKADO and RIBEIRO, 2017). This would explain the differences in the works that used the Inglehart measure and those that used the index proposed by Welzel (2013).

The profile of protest-prone citizens can be sketched as follows: more educated, a member of one or some associations and a bearer of emancipatory values. Men and young people tend to be more active in this type of engagement, but 
the coefficients are weak. It is not necessarily dissatisfied people who have a greater propensity to protest, which indicates that the normalization of protest observed in contemporary societies (MEYER and TARROW, 1996; NORRIS, 2003b) also applies to the countries analyzed. Protests are no longer an instrument of those whose demands are barred in the formal channels of representation of the political system and are engaged in by a much more plural set of actors.

How does this profile explain the phenomenon of protest in Latin America? Dictatorial regimes, conflicts and civil wars systematically dismantled traditional political mobilization agencies. Most unions and political parties were repressed until the political opening period began. In this context of repression, new social movements were organized on the basis of everyday sociability and identity (SADER, 1988), displacing the framework of collective action from the capital-labor relationship and inserting new demands into the public debate. Garretón (2002) points out that starting from the democratic opening period, the phenomenon of protest in the region started to reorganize itself around new axes, related to the improvement of democratic institutions, the deepening and recognition of social rights, the reconstruction of national economies and a new models of modernization, based on cultural and identity diversity.

Our findings point more or less in this direction. The effect of emancipatory values on political behavior leads precisely to this kind of change in the framework of collective action. The expansion of freedoms, improvements to democracy and demands for recognition of minority rights have been described in the literature as a consequence of the dispersion of such values (WELZEL, 2013). This is observed in the new forms of organization of social movements in contemporary times, where redistributive conflicts have begun to share the protest space with demands for recognition. This does not mean overcoming inequality in the region, but it does mean that new social actors have started to voice their demands through protest.

By correlating the findings of this work with recent phenomena in some countries in the region, we can find some similarities. In 2013, Brazil went through a cycle of protests initially motivated by increases in public transport fares, which soon became a movement with broad demands for more integrity from government. A similar phenomenon was observed in Chile in 2019 and led to a new 
constituent assembly being called. In Colombia, in the same year, the threat of economic reforms took the population to the streets, where they began to demand the fulfillment of peace agreements and human rights promises. In Peru, the institutional crisis between the legislature and the executive and allegations of corruption also led to protests. Finally, Uruguay and Argentina saw protests, such as the Legal Abortion campaign and Green Tide campaign, in 2013 and 2019, around feminist agendas.

Although each of the above cases has its own framework, the different protest cycles converge in demanding more responsiveness, integrity and a broadening of rights. These became part of the axes of collective action in Latin America described by Garretón (2002) in the period that followed the democratic transition. They also coincide with the dispersion of emancipatory values described by Welzel (2013). It is expected that, with greater or lesser intensity, political protest will increasingly be incorporated into the political repertoire of Latin American citizens.

\section{Conclusions}

Comparing the findings of this work with previous results, mainly those of Dalton, Van Sickle and Weldon (2010) and Ribeiro and Borba $(2015,2010)$, we can see similarities and distances. The main finding of Dalton et al. (2010) was the perception that political protests tend to happen more in more democratic societies. In the cases analyzed here, this relationship cannot be observed, since the countries that have the highest evaluations in the functioning of their democracies (Uruguay and Chile) do not have citizens with a greater propensity to protest, as shown in Graph 01. The analysis performed is descriptive and does not allow us to postulate safe inferences, but when the Latin American context is isolated, no effect of structures of opportunity is apparent.

The same authors stated that grievance would have an effect in intermediate situations: where people are neither so lacking in resources as to make political action impossible nor so rich that the nature of any discontent would be motivated by issues beyond the public sphere. Such a situation is characteristic of the countries analyzed. But discontent had modest effects. A possible 
explanation of this result is the hypothesis of Mendonça and Fuks (2015) on the 'realm of the possible'. According to these authors, in their study on the effects of discontent on political participation in Brazil, this variable would prove significant at intermediate income levels: not at such a low level that people could not see real gains from their action, or at high levels, where there is no motivation to protest. More understanding is needed on the effects of context on this measure.

Ribeiro and Borba $(2015,2010)$, in both of their works, conclude that the idea of centrality (VERBA, SCHLOZMAN, and BRADY, 1995) is more determinant for explaining the political protest than the evaluative dimension. They are inclined to derive such conclusions from reference to the effects of education on protest. According to their interpretation, cognitive resources are unevenly distributed in Latin American countries, meaning that only a small portion of the population is able to participate in protests.

The cognitive dimension expressed by formal education is the most important explanatory variable in our context. But we must disagree that education levels along can explain participation in protests. More educated individuals tend to participate in greater numbers, whether in conventional or unconventional actions. The evaluative dimension has a certain importance, as it redirects resources, whether material or cognitive, to make a protest happen, since resources are a condition for participation in protests. Without them, it is impossible to meet the costs of political action. However, only values can mobilize these resources and transform them into action. Individual motivations are fundamental in the process of channeling such resources towards political participation.

What our results indicate is that participation in protests in the countries analyzed derives from the interplay between resources (education), mobilization (membership of associations) and motivation (emancipatory values). Resources, expressed by education, are only more important in this relationship because they are a condition. In summary, people who participate in protests remain those who can, who are invited to protest and who believe that their participation is effective (UHLANER, 2001). In this sense, emancipatory values, even in developing countries, are an important motivating component for engagement in protest. Although some recent works have pointed out the limits of theories on values changes, mainly in the Brazilian context (MIGUEL, 2018), individuals who manifest such beliefs tend to 
participate more in protests. Even in Latin America, a region marked by strong social inequality, the nature of political conflict addresses the issue of values.

Translated by Robinson Fraser Submitted on November 25, 2018 Accepted on February 19, 2020

\section{References}

ALMOND, Gabriel A. and VERBA, Sidney (1963), The civic culture: political attitudes and democracy in five nations. New York: Sage. $379 \mathrm{pp}$.

ALVAREZ, R. Michael; LEVIN, Inés, and NÚÑEZ, Lucas (2017), The four faces of political participation in Argentina: using latent class analysis to study political behavior. The Journal of Politics. Vol. 79, № 04, pp. 1386-1402.

ARCE, Moisés and MANGONNET, Jorge (2013), Competitiveness, partisanship, and subnational protest in Argentina. Comparative Political Studies. Vol. 46, № 08, pp. 895-919.

BALDEZ, Lisa (2003), Women's movements and democratic transition in Chile, Brazil, East Germany, and Poland. Comparative Politics. Vol. 35, № 03, pp. 253272.

BARNES, Samuel Henry and KAASE, Max (1979), Political action: mass participation in five Western democracies. Washington: Sage Publications. 607 pp..

BENFORD, Robert D. and SNOW, David A. (2000), Framing process and social movements: an overview and assessment. Annual Review Sociology. Vol. 26, pp. 611-639.

BERTONCELO, Edison Ricardo Emiliano (2009), Eu quero votar para presidente: uma análise sobre a Campanha das Diretas. Lua Nova. Vol. 76, pp. 169-196.

BORBA, Julian (2012), Participação política: uma revisão dos modelos de classificação. Sociedade e Estado. Vol. 27, № 02, pp. 263-288.

BUUREN, Stef Van and GROOTHUIS-OUDSHOORN, Karin (2011), MICE: Multivariate imputation by chained equations in R. Journal of Statistical Software. Vol. 45, № 03, pp. 01-67.

COPPEDGE, Michael; GERRING, John; LINDBERG, Sataffan I.; SKAANING, Svend-Erik; TEORELL, Jan; KRUSELL, Joshua; MARQUARDT, Kyle L.; MECHCOVA, Valeriya; PEMSTEIN, Daniel; PERNES, Josefine; SAXER, Laura; STEPANOVA, Natalia; TZELGOV, Eitan; WANG, Yi-Ti, and WILSON, Steven (2017a), V-Dem Methodology v. 7.1. Available at <https://www.v-dem.net/en/reference/version7-1-july-2017/>. Accessed on March, 18, 2018. 
COPPEDGE, Michael; GERRING, John; LINDBERG, Staffan I.; SKAANING, Svend-Erik; TEORELL, Jan; ALTMAN, David; BERNHARD, Michael; FISH, M. Steven; GLYNN, Adam; HICKEN, Allen; KNUTSEN, Carl Henrik; KRUSELL, Joshua; LÜHRMANN, Anna; MARQUARDT, Kyle L.; McMANN, Kelly; MECHKOVA, Valeriya; OLIN, Moa; PAXTON, Pamela; PEMSTEIN, Daniel; PERNES, Josefine; PETRARCA, Constanza Sanhueza; RÖMER, Johannes von; SAXER, Laura; SEIM, Brigitte; SIGMAN, Rachel; STATON, Jeffrey; STEPANOVA, Natalia, and WILSON, Steven (2017b), $V$ Dem Dataset v7. Varieties of Democracy (V-Dem) Project. Gothenburg: V-Dem Institute. 445 pp..

DALTON, Russell; VAN SICKLE, Alix, and WELDON, Steven (2010), The individualinstitutional nexus of protest behaviour. British Journal of Political Science. Vol. 40, № 01 , pp. 51-73.

DELLA PORTA, Donatella (2010), Paths to the February 15 protest: social or political determinants? In: The world says no to war: demonstrations against the War on Iraq. Edited by WALGRAVE, Stefaan and RUCHT, Dieter. Minneapolis: University of Minnesota Press. pp. 119-140.

DELLA PORTA, Donatella and DIANI, Mario (2006), Social movements: an introduction. Oxford: Wiley-Blackwell Publishing. 356 pp..

FRASSINETTI, Antonio Murga (2009), La participación política de los estudiantes universitarios en el primer gobierno de alternancia en México. Región $Y$ Sociedad. Vol. 21, № 45, pp. 45-63.

FIORINA, Morris P. (2002), Parties, participation, and representation in America: old theories face new realities. Paper presented at 2000 Annual Meeting of the American Political Science Association.Washington.

GARRETÓN, Manuel Antonio (2002), The transformation of collective action in Latin America. CEPAL Review. Vol. 76, pp. 07-24.

GURR, Ted Robert (1970), Why men rebel. Princeton: Princeton University Press. 421 pp..

HISKEY, Jonathan T. and BOWLER, Shaun (2005), Local context and democratization in Mexico. American Journal of Political Science. Vol. 49, № 01, pp. 57-71.

INGLEHART, Ronald (1990), Culture shift: in advanced industrial society. Princeton: Princeton University Press. 504 pp..

INGLEHART, Ronald (1979), Political action: the impact of values, cognitive level and social background. In: Polical action: mass participation in five Western democracies. Edited by BARNES, Samuel Henry and KAASE, Max. Beverly Hills: Sage. pp. 343-380.

INGLEHART, Ronald and CATTERBERG, Gabriela (2002), Trends in political action: the developmental trend and the post-honeymoon decline. International Journal of Comparative Sociology. Vol. 43, № 03-05, pp. 300-316. 
INGLEHART, Ronald; HAERPFER, Christian W.; MORENO, Alejandro; WELZEL, Christian; KIZILOVA, Kseniya; DIEZ-MEDRANO, Jaime; LAGOS, Marta; NORRIS, Pipa; PONARIN, Eduard, and PURANEN, Bi et al. (eds) (2014a), World values survey: round six, integrated documentation. Available at $<$ www.worldvaluessurvey.org/WVSDocumentationWV6.jsp $>$. Accessed on February, 15, 2020.

INGLEHART, Ronald; HAERPFER, Christian W.; MORENO, Alejandro; WELZEL, Christian; KIZILOVA, Kseniya; DIEZ-MEDRANO, Jaime; LAGOS, Marta; NORRIS, Pipa; PONARIN, Eduard, and PURANEN, Bi et al. (eds) (2014b), World values survey: all rounds, country-pooled datafile version: v2018-09-12. Available at $<$ www.worldvaluessurvey.org/WVSDocumentationWV6.jsp $>$. Accessed on March, 18, 2018.

INGLEHART, Ronald; HAERPFER, Christian W.; MORENO, Alejandro; WELZEL, Christian; KIZILOVA, Kseniya; DIEZ-MEDRANO, Jaime; LAGOS, Marta; NORRIS, Pipa; PONARIN, Eduard, and PURANEN, Bi et al. (eds) (2014c), World values survey: all rounds, country-pooled datafile version: v2015-04-18. Available at $<$ http://www.worldvaluessurvey.org/WVSDocumentationWVL.jsp >. Accessed on March, 18, 2018.

JARAMILLO, Marcela Velasco (2006), Cambio institucional y protesta social en Colombia 1964-2000: análisis de series de tiempo. Colombia Internacional. № 63 , pp. 70-87.

KING, Gary; HONAKER, James; JOSEPH, Anne, and SCHEVE, Kenneth (2001), Analyzing incomplete political science data: an alternative algorithm for multiple imputation. American Political Science Review. Vol. 95, № 01, pp. 4969.

KLESNER, Joseph L. (2007), Social capital and political participation in Latin America: evidence from Argentina, Chile, Mexico, and Peru. Latin American Research Review. Vol. 42, № 02, pp. 01-32.

LEVINE, Daniel and ROMERO, Catalina (2004), Movimientos urbanos y desempoderamiento en Perú y Venezuela. América Latina Hoy. № 36, pp. 4777.

LIMA, Maria da Paz Campos and ARTILES, Antonio Martín (2013) Youth voice (s) in EU countries and social movements in southern Europe. Transfer: European Review of Labour and Research. Vol. 19, № 03, pp. 345-364.

LUSTIG, Nora; LOPES-CALVA, Luis F.; ORTIZ-JUAREZ, Eduardo, and MONGA, Célestin (2016), Deconstructing the decline in inequality. In: Inequality and growth: patterns and policy. Edited by BASU, Kaushik and STIGLITZ, Joseph E.. London: Palgrave Macmillan. pp. 212-247. 
McADAM, Doug (1999), Political process and the development of black insurgency, 1930-1970. Chicago: The University of Chicago Press. 346 pp..

McCARTHY, John D and ZALD, Mayer N. (1977), Resource mobilization and social movements: a partial theory. American Journal of Sociology. Vol. 82, № 06, pp. 1212-1241.

MENDONÇA, Clarice and FUKS, Mário (2015), Privação relativa e ativismo em protestos no Brasil: uma investigação sobre o horizonte do possível. Opinião Pública. Vol. 21, № 03, pp. 626-642.

MEYER, David S. and TARROW, Sidney (1996), The social movement society: contentious politics for a new century. Oxford: Rowman \& Littlefield. 294 pp..

MIGUEL, Luis Felipe (2018), Dominação e resistência: desafios para uma política emancipatória. São Paulo: Boitempo. 200 pp..

NORRIS, Pippa (2007), Political activism: new challenges, new opportunities. The Oxford Handbook of Comparative Politics. pp. 628-650.

NORRIS, Pippa (2003a), Democratic Phoenix: reinventing political activism. Cambridge: Cambridge University Press. 308 pp..

NORRIS, Pippa (2003b), Young people \& political activism: from the politics of loyalties to the politics of choice? Paper presented at Council of Europe Symposium.

NORRIS, Pippa; WALGRAVE, Stefaan, and AELST, Peter Van (2005), Who demonstrates? Antistate rebels, conventional participants, or everyone? Comparative Politics. Vol. 37, № 02, pp. 189-205.

O’DONNELL, Guillermo and SCHMITTER, Philippe C. (1986), Tentative conclusions about uncertain democracies. In: Transitions from authoritarian rule. Edited by O'DONNELL, Guillermo; SCHMITTER, Philippe C. and WHITEHEAD, Laurence. Vol. 04. Baltimore: Johns Hopkins University Press. pp. 01-78.

OKADO, Lucas Toshiaki Archangelo and RIBEIRO, Ednaldo Aparecido (2017), Mudança de valores em países latino-americanos: comparando os índices de pós-materialismo e valores emancipatórios. Revista Brasileira de Ciência Política. №24, pp. 07-48.

OKADO, Lucas Toshiaki Archangelo and RIBEIRO, Ednaldo Aparecido (2015), Condição juvenil e a participação política no Brasil. Paraná Eleitoral. Vol. 04, № 01, pp. 53-78.

ORTIZ-INOSTROZA, Camila and LÓPEZ, Eleonora (2017), Explorando modelos estadísticos para explicar la participación en protestas en Chile. Revista de Sociología. Vol. 32, № 01, pp. 13-31. 
PUTNAM, Robert David (2001), Bowling alone: the collapse and revival of American community. New York: Simon and Schuster. 544 pp..

QUARANTA, Mario (2015), Political protest in Western Europe: exploring the role of context in political action. Cham: Springer International Publishing. 149 pp..

RIBEIRO, Ednaldo Aparecido and BORBA, Julian (2015), Protesto político na América Latina: tendências recentes e determinantes individuais. Opinião Pública. Vol. 21, № 01, pp. 188-216.

RIBEIRO, Ednaldo Aparecido and BORBA, Julian (2010), Participação e pósmaterialismo na América Latina. Opinião Pública. Vol. 16, № 01, pp. 28-64.

RODRÍGUEZ, Edwin Cruz (2016), El ciclo de protesta 2010-2016 en Colombia. Una explicación. Jurídicas CUC. Vol. 12, № 01, pp. 31-66.

SADER, Éder (1988), Quando novos personagens entraram em cena: experiências, falas e lutas dos trabalhadores da Grande São Paulo (1970-80). São Paulo: Paz e Terra. 329 pp..

SCHRER-WARREN, Ilse and KRISCHKE, Paulo J. (1987), Uma revolução no cotidiano? Os novos movimentos sociais na América Latina. São Paulo: Brasiliense. 297 pp..

SEARS, David O. (1975), Political socialization. In: Handbook of Political Science. Edited by GREENSTEIN, Fred I. and POLSBY, Nelson W..Vol. 02. pp. 93-153.

TANASOIU, Cosmina and COLONESCU, Constantin (2008), Determinants of support for european integration: the case of Bulgaria. European Union Politics. Vol. 09, № 03 , pp. 363-377.

TATAGIBA, Luciana and GALVÃO, Andreia (2019), Os protestos no Brasil em tempos de crise (2011-2016). Opinião Pública. Vol. 25, № 01, pp. 63-96.

TESSLER, Mark; KONOLD, Carrie, and REIF, Megan (2004), Political generations in developing countries: evidence and insights from Algeria. Public Opinion Quarterly. Vol. 68, № 02, pp. 184-216.

TILLY, Charles; TARROW, Sidney, and McADAM, Doug (2009), Para mapear o confronto político. Lua Nova. № 76, pp. 11-48.

UHLANER, Carole Jean (2001), Political participation. In: International Encyclopedia of the Social \& Behavioral Sciences. Edited by SMELSER, Neil J. and BALTES, Paul B.. Orlando: Elsevier. pp. 11078-11082.

VALENZUELA, Sebastián; ARRIAGADA, Arturo, and SCHERMAN, Andrés (2012), The social media basis of youth protest behavior: the case of Chile. Journal of Communication. Vol. 62, № 02, pp. 299-314. 
VERBA, Sidney and NIE, Norman H. (1972), Participation in America: political democracy and social equality. New York: Harper and Row. 452 pp..

VERBA, Sidney; NIE, Norman H., and KIM, Jae-on (1978), Participation and political equality: a seven-nation comparison. Chicago: University of Chicago Press. 432 pp..

VERBA, Sidney; NIE, Norman H.; KIM, Jae-on (1971), The modes of democratic participation: a cross- national comparison. Beverly Hills: Sage. 80 pp..

VERBA, Sidney; SCHLOZMAN, Kay Lehman, and BRADY, Henry E. (1995), Voice and equality: civic voluntarism in American Politics. Cambridge: Harvard University Press. 664 pp..

VICH, Víctor (2004), Desobediencia simbólica: performance, participación y política al final de la dictadura fujimorista. In: La cultura en las crisis latinoamericanas. Edited by GRIMSON, Alejandro. Buenos Aires: CLACSO. pp. 63-80.

WELZEL, Christian (2013), Freedom rising: human empowerment and the quest for emancipation. Cambridge: Cambridge University Press. 472 pp..

WOOLDRIDGE, Jeffrey M. (2003), Introductory econometrics: a modern approach. Stamford: Thomson and Southwestern. 881 pp.. 


\section{Appendix}

Graph S01. Analysis of residues and expected values

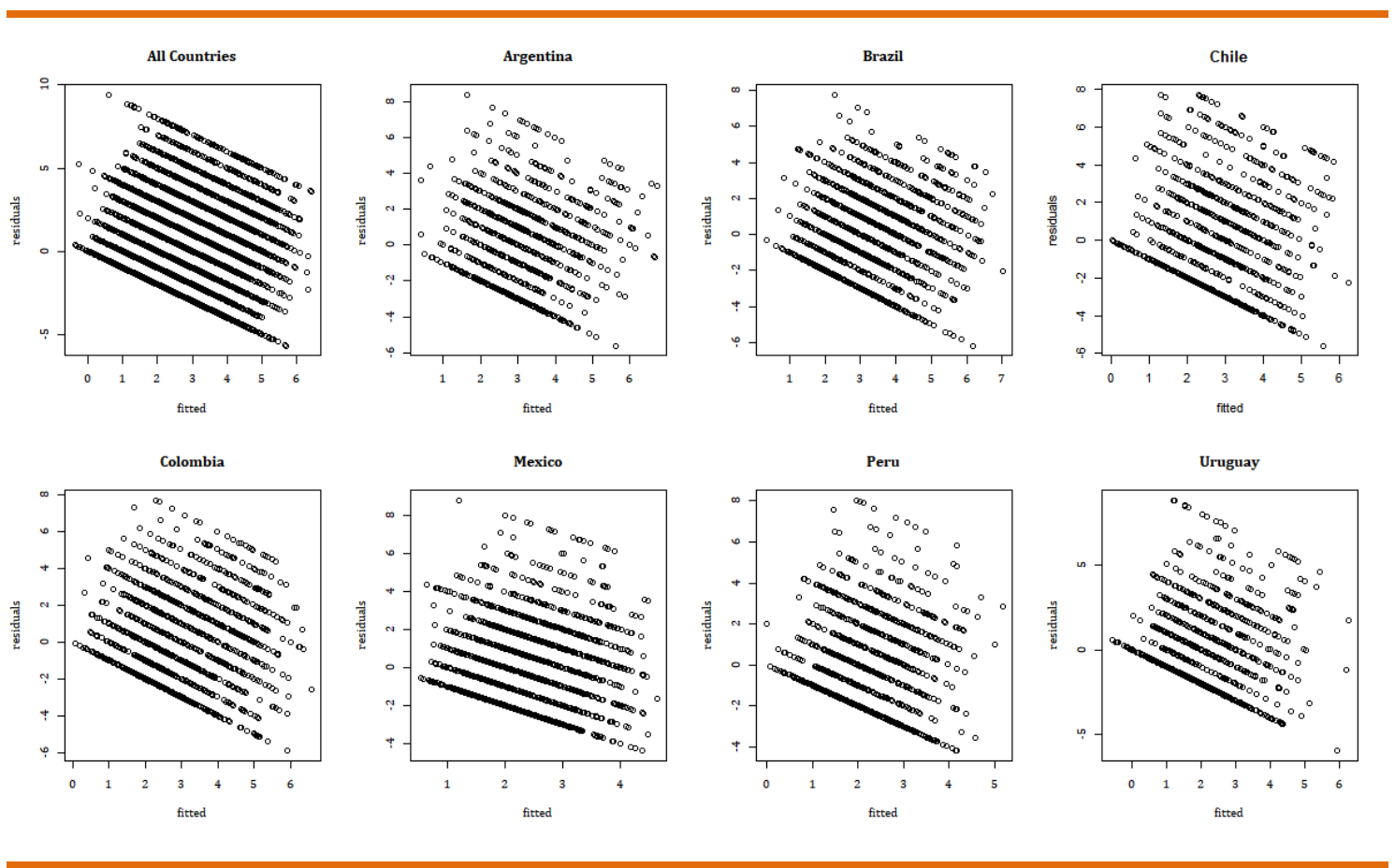

Source: Inglehart et al. (2014a).

Graph S02. Normality of residues
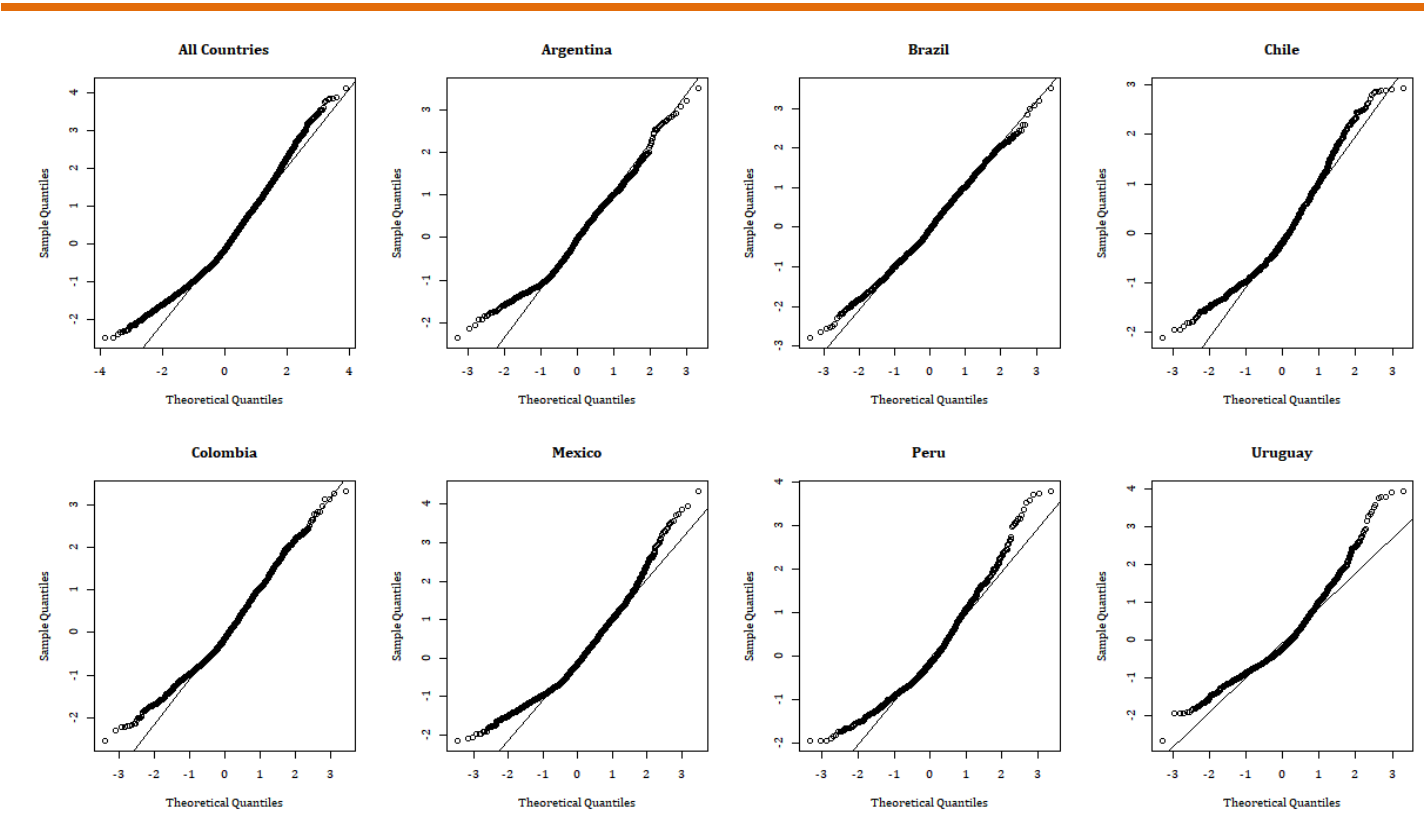

Source: Inglehart et al. (2014a). 
Table S01. Potential protest in Latin American countries: standardized coefficients

\begin{tabular}{|c|c|c|c|c|c|c|c|c|}
\hline & General & Argentina & Brazil & Chile & Colombia & Mexico & Peru & Uruguay \\
\hline & $\begin{array}{l}\text { (B Stand.) } \\
\text { (SE) }\end{array}$ & $\begin{array}{c}\text { (B Stand.) } \\
\text { (SE) }\end{array}$ & $\begin{array}{l}\text { (B Stand.) } \\
\text { (SE) }\end{array}$ & $\begin{array}{l}\text { (B Stand.) } \\
\text { (SE) }\end{array}$ & $\begin{array}{l}\text { (B Stand.) } \\
\text { (SE) }\end{array}$ & $\begin{array}{c}\text { (B Stand.) } \\
\text { (SE) }\end{array}$ & $\begin{array}{l}\text { (B Stand.) } \\
\text { (SE) }\end{array}$ & $\begin{array}{l}\text { (B Stand.) } \\
\text { (SE) }\end{array}$ \\
\hline Intercept & $\begin{array}{l}N^{* * *} \\
(N A)\end{array}$ & $\begin{array}{l}N^{* * *} \\
(N A)\end{array}$ & $\begin{array}{l}\mathrm{NA}^{* * *} \\
(\mathrm{NA})\end{array}$ & $\begin{array}{l}\text { NA } \\
(\mathrm{NA})\end{array}$ & $\begin{array}{l}\mathrm{NA}^{* * *} \\
(\mathrm{NA})\end{array}$ & $\begin{array}{l}\mathrm{NA}^{* * *} \\
\text { (NA) }\end{array}$ & $\begin{array}{l}\text { NA } \\
(\mathrm{NA})\end{array}$ & $\begin{array}{l}\text { NA } \\
\text { (NA) }\end{array}$ \\
\hline Gender & $\begin{array}{l}-0.08^{* * *} \\
(0.01)\end{array}$ & $\begin{array}{l}-0.07^{*} \\
(0.03)\end{array}$ & $\begin{array}{l}-0.13^{* * *} \\
(0.02)\end{array}$ & $\begin{array}{l}-0.09^{* *} \\
(0.03)\end{array}$ & $\begin{array}{l}-0.07^{* *} \\
(0.02)\end{array}$ & $\begin{array}{l}-0.10^{* * *} \\
(0.02)\end{array}$ & $\begin{array}{l}-0.07^{*} \\
(0.03)\end{array}$ & $\begin{array}{l}-0.07^{*} \\
(0.03)\end{array}$ \\
\hline Age & $\begin{array}{l}-0.05^{* * *} \\
(0.01)\end{array}$ & $\begin{array}{l}-0.02 \\
(0.03)\end{array}$ & $\begin{array}{l}-0.13^{* * *} \\
(0.02)\end{array}$ & $\begin{array}{l}-0.06 \\
(0.03)\end{array}$ & $\begin{array}{l}-0.07^{* *} \\
(0.02)\end{array}$ & $\begin{array}{l}-0.00 \\
(0.02)\end{array}$ & $\begin{array}{l}-0.04 \\
(0.03)\end{array}$ & $\begin{array}{l}0.02 \\
(0.03)\end{array}$ \\
\hline $\begin{array}{l}\text { Low } \\
\text { education } \\
\text { level }\end{array}$ & - & - & - & - & - & - & - & - \\
\hline $\begin{array}{l}\text { Average } \\
\text { education } \\
\text { level }\end{array}$ & $\begin{array}{l}0.10^{* * *} \\
(0.01)\end{array}$ & $\begin{array}{l}0.09^{* *} \\
(0.03)\end{array}$ & $\begin{array}{l}0.13^{* * *} \\
(0.03)\end{array}$ & $\begin{array}{l}0.04 \\
(0.04)\end{array}$ & $\begin{array}{l}0.13^{* * *} \\
(0.03)\end{array}$ & $\begin{array}{l}0.08^{* *} \\
(0.03)\end{array}$ & $\begin{array}{l}0.05 \\
(0.03)\end{array}$ & $\begin{array}{l}0.11^{* * *} \\
(0.03)\end{array}$ \\
\hline $\begin{array}{l}\text { High } \\
\text { education } \\
\text { level }\end{array}$ & $\begin{array}{l}0.24^{* * *} \\
(0.01)\end{array}$ & $\begin{array}{l}0.23^{* * *} \\
(0.04)\end{array}$ & $\begin{array}{l}0.29^{\text {*** }} \\
(0.03)\end{array}$ & $\begin{array}{l}0.10^{*} \\
(0.04)\end{array}$ & $\begin{array}{l}0.35^{\text {*** }} \\
(0.03)\end{array}$ & $\begin{array}{l}0.21^{* * *} \\
(0.03)\end{array}$ & $\begin{array}{l}0.22^{\text {*** }} \\
(0.03)\end{array}$ & $\begin{array}{l}0.19^{\text {*** }} \\
(0.03)\end{array}$ \\
\hline Income & $\begin{array}{l}-0.01 \\
(0.01)\end{array}$ & $\begin{array}{l}-0.06 \\
(0.03)\end{array}$ & $\begin{array}{l}-0.04 \\
(0.02)\end{array}$ & $\begin{array}{l}0.00 \\
(0.03)\end{array}$ & $\begin{array}{l}-0.03 \\
(0.02)\end{array}$ & $\begin{array}{l}0.02 \\
(0.02)\end{array}$ & $\begin{array}{l}-0.02 \\
(0.03)\end{array}$ & $\begin{array}{l}0.07^{*} \\
(0.03)\end{array}$ \\
\hline $\begin{array}{l}\text { Membership } \\
\text { of } \\
\text { associations }\end{array}$ & $\begin{array}{l}0.13^{\text {*** }} \\
(0.01)\end{array}$ & $\begin{array}{l}0.12^{* * *} \\
(0.03)\end{array}$ & $\begin{array}{l}0.11^{* * *} \\
(0.02)\end{array}$ & $\begin{array}{l}0.17^{* * *} \\
(0.03)\end{array}$ & $\begin{array}{l}0.12^{* * *} \\
(0.02)\end{array}$ & $\begin{array}{l}0.13^{* * *} \\
(0.02)\end{array}$ & $\begin{array}{l}0.09^{\text {*** }} \\
(0.03)\end{array}$ & $\begin{array}{l}0.17^{* * *} \\
(0.03)\end{array}$ \\
\hline Grievance & $\begin{array}{l}-0.03^{* * *} \\
(0.01)\end{array}$ & $\begin{array}{l}-0.03 \\
(0.03)\end{array}$ & $\begin{array}{l}0.01 \\
(0.02)\end{array}$ & $\begin{array}{l}-0.02 \\
(0.03)\end{array}$ & $\begin{array}{l}-0.09^{* * *} \\
(0.02)\end{array}$ & $\begin{array}{l}-0.06^{* *} \\
(0.02)\end{array}$ & $\begin{array}{l}-0.02 \\
(0.03)\end{array}$ & $\begin{array}{l}-0.03 \\
(0.03)\end{array}$ \\
\hline $\begin{array}{l}\text { Trust in } \\
\text { institutions }\end{array}$ & $\begin{array}{l}0.07^{* * *} \\
(0.01)\end{array}$ & $\begin{array}{l}-0.02 \\
(0.03)\end{array}$ & $\begin{array}{l}0.09^{* * *} \\
(0.02)\end{array}$ & $\begin{array}{l}0.02 \\
(0.03)\end{array}$ & $\begin{array}{l}0.12^{* * *} \\
(0.02)\end{array}$ & $\begin{array}{l}0.10^{* * *} \\
(0.02)\end{array}$ & $\begin{array}{l}0.10^{* * *} \\
(0.03)\end{array}$ & $\begin{array}{l}0.06^{*} \\
(0.03)\end{array}$ \\
\hline $\begin{array}{l}\text { Emancipatory } \\
\text { values }\end{array}$ & $\begin{array}{l}0.20^{* * *} \\
(0.01)\end{array}$ & $\begin{array}{l}0.24^{\text {*** }} \\
(0.03)\end{array}$ & $\begin{array}{l}0.19^{\text {*** }} \\
(0.02)\end{array}$ & $\begin{array}{l}0.28^{\text {*** }} \\
(0.03)\end{array}$ & $\begin{array}{l}0.15^{\text {*** }} \\
(0.02)\end{array}$ & $\begin{array}{l}0.10^{* * *} \\
(0.02)\end{array}$ & $\begin{array}{l}0.22^{* * *} \\
(0.03)\end{array}$ & $\begin{array}{l}0.22^{\text {*** }} \\
(0.03)\end{array}$ \\
\hline Argentina & - & - & - & - & - & - & - & - \\
\hline Brazil & $\begin{array}{l}0.06^{* * *} \\
(0.01)\end{array}$ & - & - & - & - & - & - & - \\
\hline Chile & $\begin{array}{l}-0.05^{* * *} \\
(0.01)\end{array}$ & - & - & - & - & - & - & - \\
\hline Colombia & $\begin{array}{l}0.00 \\
(0.01)\end{array}$ & - & - & - & - & - & - & - \\
\hline Mexico & $\begin{array}{l}-0.12^{* * *} \\
(0.02)\end{array}$ & - & - & - & - & - & - & - \\
\hline Peru & $\begin{array}{l}-0.11^{* * *} \\
(0.01)\end{array}$ & - & - & - & - & - & - & - \\
\hline Uruguay & $\begin{array}{l}-0.12^{* * *} \\
(0.01)\end{array}$ & - & - & - & - & - & - & - \\
\hline $\mathrm{N}$ & 9238 & 1030 & 1486 & 1000 & 1512 & 2000 & 1210 & 1000 \\
\hline $\begin{array}{l}\mathrm{R}^{2} / \\
\text { adjusted } \mathrm{R}^{2}\end{array}$ & $\begin{array}{l}0.190 / \\
0.188\end{array}$ & $\begin{array}{l}0.167 / \\
0.160\end{array}$ & $\begin{array}{l}0.226 / \\
0.222\end{array}$ & $\begin{array}{l}0.160 / \\
0.1502\end{array}$ & $\begin{array}{l}0.226 / \\
0.2201\end{array}$ & $\begin{array}{l}0.129 / \\
0.126\end{array}$ & $\begin{array}{l}0.143 / \\
0.137\end{array}$ & $\begin{array}{l}0.198 / \\
0.1901\end{array}$ \\
\hline
\end{tabular}

